Article

\title{
Construction of $\mathrm{Ag}_{3} \mathrm{PO}_{4} / \mathrm{SnO}_{2}$ Heterojunction on Carbon Cloth with Enhanced Visible Light Photocatalytic Degradation
}

\author{
Min Liu ${ }^{1, * \mathbb{C}}$, Guangxin Wang ${ }^{2}$, Panpan $\mathrm{Xu}^{2, *}$, Yanfeng $\mathrm{Zhu}^{3}$ and Wuhui $\mathrm{Li}^{3}{ }^{\mathbb{C}}$ \\ 1 School of Electrical Engineering, Henan University of Science and Technology, Luoyang 471023, China \\ 2 Research Center for High Purity Materials, School of Materials Science and Engineering, Henan University \\ of Science and Technology, Luoyang 471023, China; wgx58@126.com \\ 3 School of Materials Science and Engineering, Henan University of Science and Technology, \\ Luoyang 471023, China; zyf2273@163.com (Y.Z.); fxcszx_haust@163.com (W.L.) \\ * Correspondence: liumin1086@163.com (M.L.); xupanpan213@163.com (P.X.); Tel.: +86-379-6562-7697 (M.L.)
}

Received: 9 February 2020; Accepted: 2 May 2020; Published: 7 May 2020

\begin{abstract}
In this study, the $\mathrm{Ag}_{3} \mathrm{PO}_{4} / \mathrm{SnO}_{2}$ heterojunction on carbon cloth $\left(\mathrm{Ag}_{3} \mathrm{PO}_{4} / \mathrm{SnO}_{2} / \mathrm{CC}\right)$ was successfully fabricated via a facile two-step process. The results showed that the $\mathrm{Ag}_{3} \mathrm{PO}_{4} / \mathrm{SnO}_{2} / \mathrm{CC}$ heterojunction exhibited a remarkable photocatalytic performance for the degradation of Rhodamine $\mathrm{B}(\mathrm{RhB})$ and methylene blue (MB), under visible light irradiation. The calculated $\mathrm{k}$ values for the degradation of $\mathrm{RhB}$ and $\mathrm{MB}$ over $\mathrm{Ag}_{3} \mathrm{PO}_{4} / \mathrm{SnO}_{2} / \mathrm{CC}$ are $0.04716 \mathrm{~min}^{-1}$ and $0.04916 \mathrm{~min}^{-1}$, which are higher than those calculated for the reactions over $\mathrm{Ag}_{3} \mathrm{PO}_{4} / \mathrm{SnO}_{2}, \mathrm{Ag}_{3} \mathrm{PO}_{4} / \mathrm{CC}$ and $\mathrm{SnO}_{2} / \mathrm{CC}$, respectively. The enhanced photocatalytic activity could mainly be attributed to the improved separation efficiency of photogenerated electron-hole pairs, after the formation of the $\mathrm{Ag}_{3} \mathrm{PO}_{4} / \mathrm{SnO}_{2} / \mathrm{CC}$ heterojunction. Moreover, carbon cloth with a large specific surface area and excellent conductivity was used as the substrate, which helped to increase the contact area of dye solution with photocatalysts and the rapid transfer of photogenerated electrons. Notably, when compared with the powder catalyst, the catalysts supported on carbon cloth are easier to quickly recycle from the pollutant solution, thereby reducing the probability of recontamination.
\end{abstract}

Keywords: $\mathrm{Ag}_{3} \mathrm{PO}_{4} / \mathrm{SnO}_{2}$; heterojunction; carbon cloth; photocatalytic activity; visible light

\section{Introduction}

In the last few decades, with the rapid development of social economies and the continuous expansion of industrial production, environmental pollution has become one of the most important issues in society. In particular, the polluted water from organic dyes, such as Rhodamine B (RhB), has become a serious threat to the environment and human health [1-5]. Semiconductor photocatalysts can degrade organic pollutants in wastewater under solar light irradiation, saving energy and protecting the environment, and thus attracting tremendous attention [6-8]. However, traditional semiconductor photocatalysts can only respond to ultraviolet irradiation that occupies about $5 \%$ of solar light, which severely limits their practical applications in the utilization of solar light [9-13]. Therefore, it is urgent to develop photocatalysts that can be excited under visible light irradiation [14].

In recent years, silver-based photocatalysts have attracted widespread attention. Among them, $\mathrm{Ag}_{3} \mathrm{PO}_{4}$ has been extensively studied due to its narrow band gap (about $2.40 \mathrm{eV}$ ) and excellent photocatalytic activity under visible light [15-17]. However, the speedy recombination of photoexcited electron-hole pairs and poor light stability severely weakens its photocatalytic performance [18-22]. Subsequently, combining $\mathrm{Ag}_{3} \mathrm{PO}_{4}$ with other semiconductors to form heterojunction has proved to be a promising strategy [23-27]. 
As a direct wide-bandgap semiconductor, $\mathrm{SnO}_{2}$ has been widely applied to catalysts, gas sensing and batteries [28-32]. Due to its good conductivity and stability, $\mathrm{SnO}_{2}$ is often combined with other semiconductors to form heterojunction, which promotes the separation of photogenerated electron-hole pairs [33-35]. For example, $\mathrm{Ag}_{3} \mathrm{PO}_{4} / \mathrm{SnO}_{2}$ [36,37], $\mathrm{Ag}_{3} \mathrm{PO}_{4} / \mathrm{SnO}_{2} /$ porcine bone [38], $\mathrm{AgCl} / \mathrm{SnO}_{2}$ [39] and $\mathrm{Ag} / \mathrm{AgCl} / \mathrm{SnO}_{2}$ [40], show enhanced photocatalytic activity over a single photocatalyst.

In addition, in order to overcome the difficulty in recycling the powder photocatalyst, carbon cloth is usually used for photocatalyst support [5,41,42]. Xu et al. designed and prepared $\mathrm{TiO}_{2} /$ $\mathrm{Bi}_{2} \mathrm{WO}_{6}$ nanostructured heterojunctions on carbon fibers, as an effective and weaveable visible-light photocatalyst [5]. Shen et al. reported on the design and preparation of $\mathrm{C}_{3} \mathrm{~N}_{4}$ nanosheets on carbon-fiber cloth as a filter-membrane-shaped photocatalyst [41]. Zhang et al. successfully prepared the heterostructures of $\mathrm{CuS} / \mathrm{ZnO} / \mathrm{CFs}$, which showed improved photocatalytic activity in the degradation of methylene blue (MB), under visible light irradiation [42]. This is mainly because carbon cloth has a large specific surface area, excellent conductivity and good stability $[43,44]$. This not only facilitates the recovery of the photocatalyst, but also helps to increase the contact area of the photocatalyst with the organic dye solution and sunlight, in turn quickly transferring the photogenerated electrons to enhance the separation efficiency of photogenerated electron-hole pairs [45].

Herein, we synthesized $\mathrm{Ag}_{3} \mathrm{PO}_{4} / \mathrm{SnO}_{2}$ heterojunction on carbon cloth using a two-step method. The results showed that the $\mathrm{Ag}_{3} \mathrm{PO}_{4} / \mathrm{SnO}_{2} / \mathrm{CC}$ heterojunction exhibited a remarkable photocatalytic performance for the degradation of $\mathrm{RhB}$ under the visible light irradiation. Furthermore, the structure and possible mechanism of the enhanced photocatalytic activity of the $\mathrm{Ag}_{3} \mathrm{PO}_{4} / \mathrm{SnO}_{2} / \mathrm{CC}$ heterojunction are discussed in detail.

\section{Experimental}

\subsection{Synthesis of $\mathrm{SnO}_{2}$ Nanorods on Carbon Cloth}

A piece of carbon cloth $(2.5 \mathrm{~cm} \times 2.0 \mathrm{~cm}$, WOS 1009, CeTech, Thickness: $0.33 \mathrm{~mm}$, Basic Weight: $120 \mathrm{~g} / \mathrm{m}^{2}$ ) was put into concentrated $\mathrm{HNO}_{3}$ at $100{ }^{\circ} \mathrm{C}$ for $90 \mathrm{~min}$. It was then cleaned with deionized water and acetone for several times, and dried at $80^{\circ} \mathrm{C}$. The $\mathrm{SnO}_{2}$ nanorods were grown on carbon cloth $\left(\mathrm{SnO}_{2} / \mathrm{CC}\right)$ through a facile hydrothermal route [46]. $1.1 \mathrm{~mol} / \mathrm{L} \mathrm{NaOH}$ solution was added into $0.1 \mathrm{~mol} / \mathrm{L} \mathrm{SnCl}_{4} \cdot 5 \mathrm{H}_{2} \mathrm{O}$ solution, drop by drop, under a constant stirring condition. After stirring for $30 \mathrm{~min}$, the $35 \mathrm{~mL}$ mixture solution and the carbon cloth were added into a $50 \mathrm{~mL}$ Teflon-lined stainless steel autoclave, and hydrothermally treated at $200{ }^{\circ} \mathrm{C}$ for $12 \mathrm{~h}$. Eventually, the carbon cloth was taken out, rinsed with deionized water and air-dried at $80^{\circ} \mathrm{C}$ for $12 \mathrm{~h}$.

\subsection{Synthesis of $\mathrm{Ag}_{3} \mathrm{PO}_{4} / \mathrm{SnO}_{2}$ Heterojunction on Carbon Cloth}

The $\mathrm{Ag}_{3} \mathrm{PO}_{4} / \mathrm{SnO}_{2}$ heterojunction on carbon cloth were produced through a facile dipping method [47]. More specifically, the $\mathrm{SnO}_{2} / \mathrm{CC}$ was first placed into the $0.05 \mathrm{~mol} / \mathrm{L} \mathrm{AgNO}_{3}$ solution for $20 \mathrm{~h}$. Next, the $\mathrm{SnO}_{2} / \mathrm{CC}$ was taken out and immersed into the $0.05 \mathrm{~mol} / \mathrm{L} \mathrm{Na}_{2} \mathrm{HPO}_{4}$ solution for $2 \mathrm{~min}$. Subsequently, the $\mathrm{SnO}_{2} / \mathrm{CC}$ was put back into the $\mathrm{AgNO}_{3}$ solution for $2 \mathrm{~min}$. The immersion process was repeated 20 times. Eventually, the prepared $\mathrm{Ag}_{3} \mathrm{PO}_{4} / \mathrm{SnO}_{2} / \mathrm{CC}$ was cleaned with deionized water and dried at $80^{\circ} \mathrm{C}$ for $12 \mathrm{~h}$. For comparison, the $\mathrm{Ag}_{3} \mathrm{PO}_{4}$ grown on carbon cloth $\left(\mathrm{Ag}_{3} \mathrm{PO}_{4} / \mathrm{CC}\right)$, was fabricated in the same process.

\subsection{Characterization}

The as-prepared samples were characterized using the X-ray diffractometer (XRD, D8 advance, Bruker, Karlsruhe, Germany), field emission scanning electron microscope (FESEM, JSM-7800F, JEOL Ltd., Tokyo, Japan, precision: $0.8 \mathrm{~nm}$ ), transmission electron microscope (TEM, JSM-2100F, $200 \mathrm{kV}$, Hitachinaka, Naka, Japan, Line resolution: $0.14 \mathrm{~nm}$ ), high-resolution transmission electron microscope (HRTEM, FEI, TecnaiG2 F30, 200 kV, Hitachinaka, Naka, Japan), X-ray photoelectron spectroscopy (XPS, NEXSA, precision: $\pm 0.1 \%$ ), and the Brunauer-Emmett-Teller method (BET, Micromeritics ASAP 
2460, precision: $\pm 0.1 \%$ ), respectively. The elemental mapping studies were carried out under the SEM. The photoluminescence (PL) properties were analyzed using the fluorescence spectrophotometer (F-7000, precision: $1 \mathrm{~nm}$ ), with a Xe lamp. The UV-Vis diffuse reflectance spectroscopy was performed on a Shimadzu UV-3600 (precision: $0.1 \mathrm{~nm}$ ) spectrophotometer. The absorption spectra of the as-prepared samples were obtained using an ultraviolet-visible spectrophotometer (UV-vis, U-3310, Hitachi Ltd., Tokyo, Japan).

\subsection{Photocatalytic Activity}

The photocatalytic activity of the as-prepared samples was evaluated by the photodegradation of $\mathrm{RhB}$ and $\mathrm{MB}$, where a $300 \mathrm{~W}$ xenon light with a $420 \mathrm{~nm}$ cut off filter was chosen as the visible-light source. The synthesized $\mathrm{SnO}_{2} / \mathrm{CC}\left(\mathrm{SnO}_{2}: 30.6 \mathrm{mg}\right), \mathrm{Ag}_{3} \mathrm{PO}_{4} / \mathrm{CC}\left(\mathrm{Ag}_{3} \mathrm{PO}_{4}: 5.1 \mathrm{mg}\right)$ and $\mathrm{Ag}_{3} \mathrm{PO}_{4} / \mathrm{SnO}_{2} / \mathrm{CC}$ $\left(\mathrm{Ag}_{3} \mathrm{PO}_{4}: 8.2 \mathrm{mg}\right)$ samples were put into the $50 \mathrm{~mL} \mathrm{RhB}\left(4 \times 10^{-5} \mathrm{~mol} / \mathrm{L}\right)$ and $\mathrm{MB}\left(5 \times 10^{-5} \mathrm{~mol} / \mathrm{L}\right)$ aqueous solution. The mass loading of $\mathrm{Ag}_{3} \mathrm{PO}_{4}$ and $\mathrm{SnO}_{2}$ powder was weighed using an electronic analytical balance (ME104E, max weight: $120 \mathrm{~g}$, precision: $0.1 \mathrm{mg}$, linear error: $0.2 \mathrm{mg}$ ), according to the reading difference between the substrates and loading samples. The suspension was stirred in the dark for $60 \mathrm{~min}$ to attain the adsorption-desorption equilibrium. During the irradiation experiment, approximately $3 \mathrm{~mL}$ of the suspensions was removed every $10 \mathrm{~min}$. Finally, the concentration of $\mathrm{RhB}$ solution was monitored as a function of irradiation time, using the UV-vis spectrophotometer.

\section{Results and Discussion}

\subsection{Microstructure and Morphology}

The crystal structure of the synthesized samples is confirmed by XRD characterization, shown in Figure 1. For the pure CC sample, the diffraction peaks at around $26^{\circ}$ and $44^{\circ}$ correspond with the carbon cloth (JCPDS card No. 65-6212) [46]. All the diffraction peaks of the $\mathrm{Ag}_{3} \mathrm{PO}_{4} / \mathrm{SnO}_{2} / \mathrm{CC}$ sample can be indexed to the tetragonal rutile phase of $\mathrm{SnO}_{2}$ (JCPDS card No. 41-1445), $\mathrm{Ag}_{3} \mathrm{PO}_{4}$ (JCPDS card No. 06-0505) and CC $[48,49]$. No diffraction peaks belonging to the impurity phases were detected.

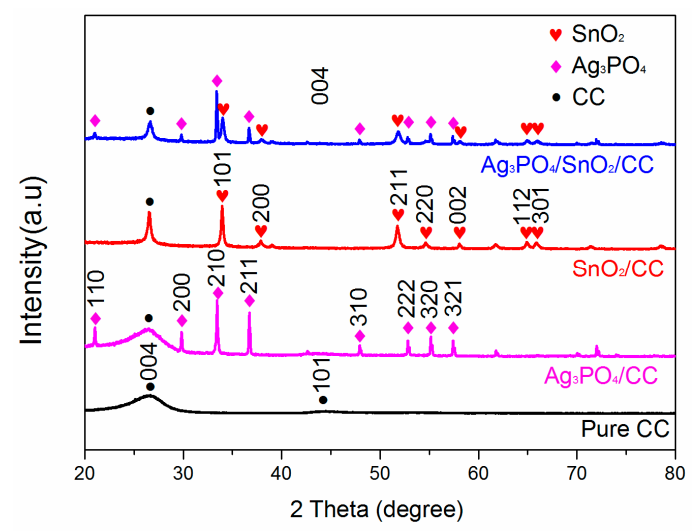

Figure 1. XRD patterns of pure CC, $\mathrm{Ag}_{3} \mathrm{PO}_{4} / \mathrm{CC}, \mathrm{SnO}_{2} / \mathrm{CC}$ and $\mathrm{Ag}_{3} \mathrm{PO}_{4} / \mathrm{SnO}_{2} / \mathrm{CC}$.

As illustrated in Figure 2a,b, $\mathrm{SnO}_{2}$ nanorods with a diameter of about 150-300 nm grow evenly on the surface of the carbon cloth. In contrast, it can be clearly seen from the photographs in Figure 2c that only a few $\mathrm{Ag}_{3} \mathrm{PO}_{4}$ particles are sparsely deposited on the carbon cloth. The enlarged SEM image shows that $\mathrm{Ag}_{3} \mathrm{PO}_{4}$ consists of spherical particles and some particles with irregular shapes. The SEM images of the $\mathrm{Ag}_{3} \mathrm{PO}_{4} / \mathrm{SnO}_{2} / \mathrm{CC}$ sample are shown in Figure 2e,f. When compared with the $\mathrm{Ag}_{3} \mathrm{PO}_{4} / \mathrm{CC}$ sample, many more $\mathrm{Ag}_{3} \mathrm{PO}_{4}$ particles with irregular shapes are deposited on the carbon cloth, which should be attributed to the manufacturing process. It can clearly be seen from the SEM results that the surface of the carbon cloth is smooth, while the $\mathrm{SnO}_{2} / \mathrm{CC}$ sample shows a rougher surface. When the $\mathrm{SnO}_{2} / \mathrm{CC}$ was put into the $\mathrm{AgNO}_{3}$ solution, many more $\mathrm{Ag}^{+}$ions were easily adsorbed onto the surface 
of $\mathrm{SnO}_{2} / \mathrm{CC}$. They then reacted with $\mathrm{Na}_{2} \mathrm{HPO}_{4}$ to generate $\mathrm{Ag}_{3} \mathrm{PO}_{4}$, which was more difficult to shed from the surface of $\mathrm{SnO}_{2} / \mathrm{CC}$, compared to that on the carbon cloth. This is also evidenced by the weight of the synthesized samples.
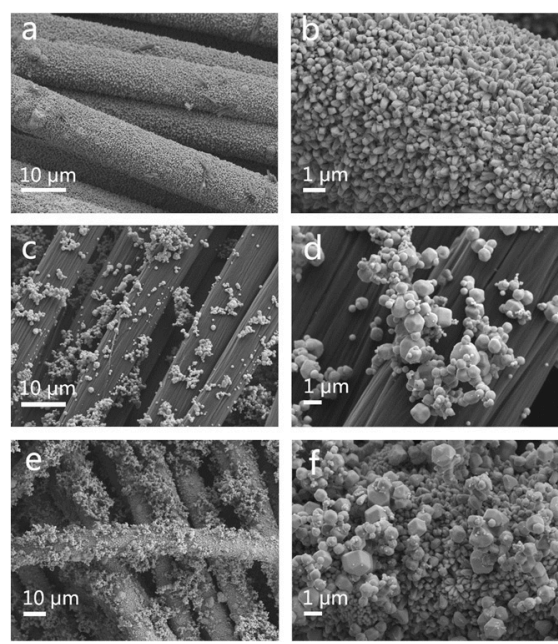

Figure 2. SEM images of the $\mathrm{SnO}_{2} / \mathrm{CC}(\mathbf{a}, \mathbf{b}), \mathrm{Ag}_{3} \mathrm{PO}_{4} / \mathrm{CC}(\mathbf{c}, \mathbf{d}), \mathrm{Ag}_{3} \mathrm{PO}_{4} / \mathrm{SnO}_{2} / \mathrm{CC}(\mathbf{e}, \mathbf{f})$.

Furthermore, the elemental mapping analysis of the $\mathrm{Ag}_{3} \mathrm{PO}_{4} / \mathrm{SnO}_{2} / \mathrm{CC}$ sample for the detected elements $\mathrm{Sn}, \mathrm{O}, \mathrm{Ag}, \mathrm{P}$ and $\mathrm{C}$, is shown in Figure $3 \mathrm{a}-\mathrm{g}$. All five elements are uniformly distributed throughout the whole carbon fiber. In addition, Figure 3 clearly shows the distribution of $\mathrm{Sn}, \mathrm{O}, \mathrm{Ag}$ and $\mathrm{P}$ within the carbon fiber, which further confirms the formation of the $\mathrm{Ag}_{3} \mathrm{PO}_{4} / \mathrm{SnO}_{2} / \mathrm{CC}$ heterojunction structure [50].
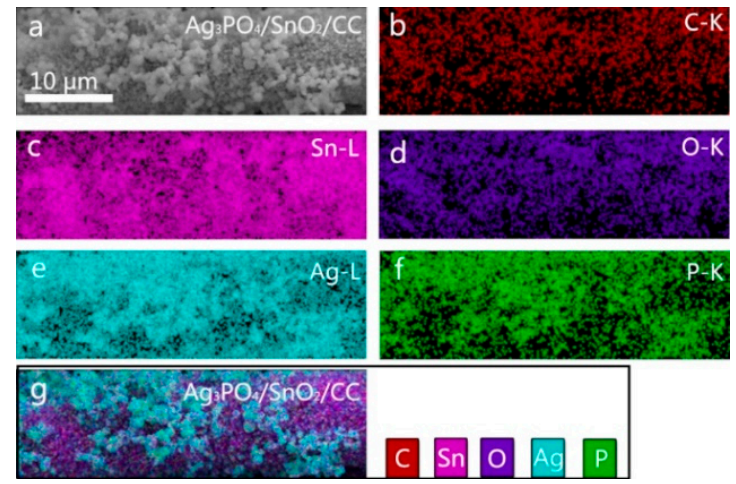

Figure 3. SEM image of $\mathrm{Ag}_{3} \mathrm{PO}_{4} / \mathrm{SnO}_{2} / \mathrm{CC}(\mathbf{a})$ and the elemental mapping images of $\mathrm{C}(\mathbf{b}), \mathrm{Sn}(\mathbf{c}), \mathrm{O}(\mathbf{d})$, $\mathrm{Ag}(\mathbf{e}), \mathrm{P}(\mathbf{f})$ and $\mathrm{Ag}_{3} \mathrm{PO}_{4} / \mathrm{SnO}_{2} / \mathrm{CC}(\mathbf{g})$.

The TEM image of the $\mathrm{Ag}_{3} \mathrm{PO}_{4} / \mathrm{SnO}_{2} / \mathrm{CC}$ is shown in Figure $4 \mathrm{a}$, which clearly indicates that the $\mathrm{Ag}_{3} \mathrm{PO}_{4}$ particles are uniformly distributed on $\mathrm{SnO}_{2}$ nanorods. The HRTEM image of $\mathrm{Ag}_{3} \mathrm{PO}_{4} / \mathrm{SnO}_{2} / \mathrm{CC}$ is shown in Figure $4 \mathrm{~b}$, which clearly uncovers a set of fringes with an interplanar spacing of $0.246 \mathrm{~nm}$ ascribed to the (211) plane of $\mathrm{Ag}_{3} \mathrm{PO}_{4}$, and the other lattice fringe of $0.336 \mathrm{~nm}$ consistent with the (110) plane of $\mathrm{SnO}_{2}[48,51]$. The results above confirm the formation of the $\mathrm{Ag}_{3} \mathrm{PO}_{4} / \mathrm{SnO}_{2}$ heterojunction.

XPS was utilized to further analyze the elemental compositions of the as-prepared samples (Figure 5). In the wide-scan, sharp peaks of $\mathrm{Sn}, \mathrm{Ag}, \mathrm{P}, \mathrm{O}$ and $\mathrm{C}$ are detected in $\mathrm{Ag}_{3} \mathrm{PO}_{4} / \mathrm{SnO}_{2} / \mathrm{CC}$ (Figure 5a). Analysis of the XPS spectrum for Sn 3d, Ag 3d, and P 2p is shown in Figure 5b-d. The peaks located at 486.5 and $494.8 \mathrm{eV}$ (Figure $5 \mathrm{~b}$ ), can be indexed to $\mathrm{Sn} 3 \mathrm{~d}_{5 / 2}$ and $\mathrm{Sn} 3 \mathrm{~d}_{3 / 2}$ in $\mathrm{SnO}_{2}$ [52]. Meanwhile, two sharp peaks at 367.7 and $373.8 \mathrm{eV}$ (Figure $5 \mathrm{c}$ ), can be ascribed to $\mathrm{Ag} 3 \mathrm{~d}_{3 / 2}$ and $\mathrm{Ag} 3 \mathrm{~d}_{5 / 2}$ of $\mathrm{Ag}^{+}$ions, respectively [16]. The characteristic peak (P 2p) at $132.8 \mathrm{eV}$ (Figure 5d), corresponds to $\mathrm{P}^{5+}$, 
according to previous literature [18]. All these characterizations implied that the $\mathrm{Ag}_{3} \mathrm{PO}_{4} / \mathrm{SnO}_{2} / \mathrm{CC}$ heterojunction was successfully prepared.
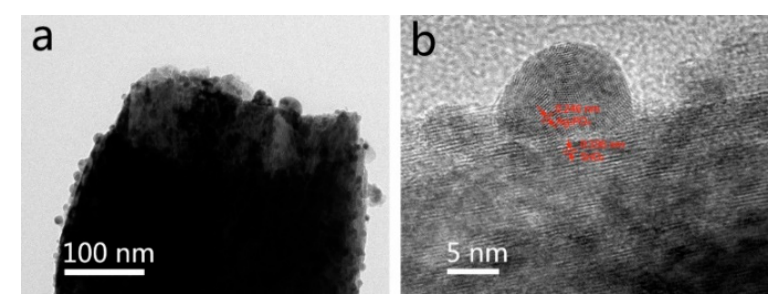

Figure 4. TEM image of $\mathrm{Ag}_{3} \mathrm{PO}_{4} / \mathrm{SnO}_{2} / \mathrm{CC}$ (a). HRTEM image of $\mathrm{Ag}_{3} \mathrm{PO}_{4} / \mathrm{SnO}_{2} / \mathrm{CC}$ (b).
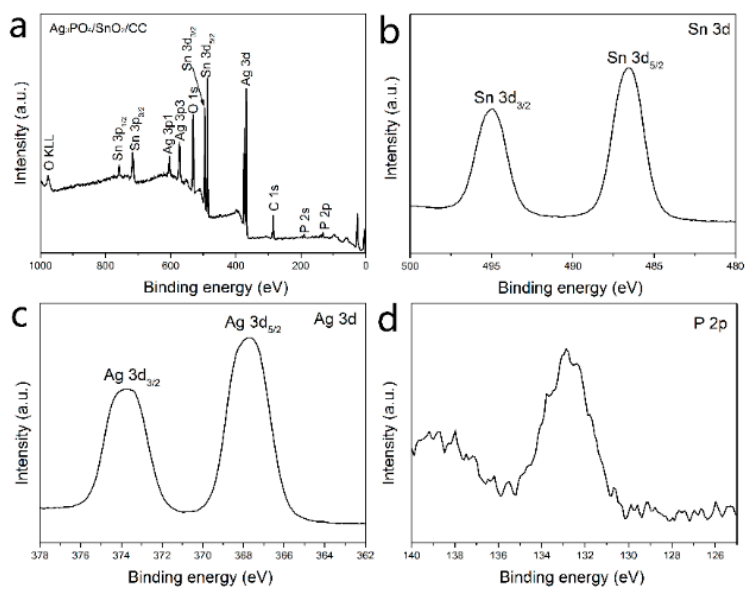

Figure 5. XPS spectra of the $\mathrm{Ag}_{3} \mathrm{PO}_{4} / \mathrm{SnO}_{2} / \mathrm{CC}$ : (a) survey spectrum, (b) Sn 3d, (c) $\mathrm{Ag} 3 \mathrm{~d}$, (d) P 2p.

Figure 6a shows the UV-vis diffuse reflectance spectra of $\mathrm{SnO}_{2}, \mathrm{Ag}_{3} \mathrm{PO}_{4}, \mathrm{Ag}_{3} \mathrm{PO}_{4} / \mathrm{CC}, \mathrm{SnO}_{2} / \mathrm{CC}$ and $\mathrm{Ag}_{3} \mathrm{PO}_{4} / \mathrm{SnO}_{2} / \mathrm{CC}$. As illustrated in Figure 6a, $\mathrm{Ag}_{3} \mathrm{PO}_{4}$ showed photoabsorption in the visible light region, and $\mathrm{SnO}_{2}$ demonstrated no absorption of visible light. $\mathrm{SnO}_{2} / \mathrm{CC}$ was similar to the absorption edge of pure $\mathrm{SnO}_{2}$, while there was an obvious absorption tail in the long-wavelength region (400-800 nm), which could have resulted from the scattering and absorption of light among the texture and pore structure in $\mathrm{CC}$ [41]. $\mathrm{Ag}_{3} \mathrm{PO}_{4} / \mathrm{CC}$ differs from the absorption edge of pure $\mathrm{Ag}_{3} \mathrm{PO}_{4}$ in the short-wavelength region (200-400 nm). This may be related to the low content of $\mathrm{Ag}_{3} \mathrm{PO}_{4}$ deposited on carbon cloth. The obtained $\mathrm{Ag}_{3} \mathrm{PO}_{4} / \mathrm{SnO}_{2} / \mathrm{CC}$ heterojunction performs a wide and strong absorption in the visible region, and it also has an increased absorption tail in the long-wavelength region (400-800 nm). Figure $6 \mathrm{~b}$ displays the corresponding Tauc's plots of $(\alpha \mathrm{hv})^{2} \mathrm{vs}$. (hv) of $\mathrm{Ag}_{3} \mathrm{PO}_{4}$ and $\mathrm{SnO}_{2}$, which showed that the band gap of $\mathrm{Ag}_{3} \mathrm{PO}_{4}$ and $\mathrm{SnO}_{2}$ was estimated to be 2.42 and $3.6 \mathrm{eV}$, respectively.
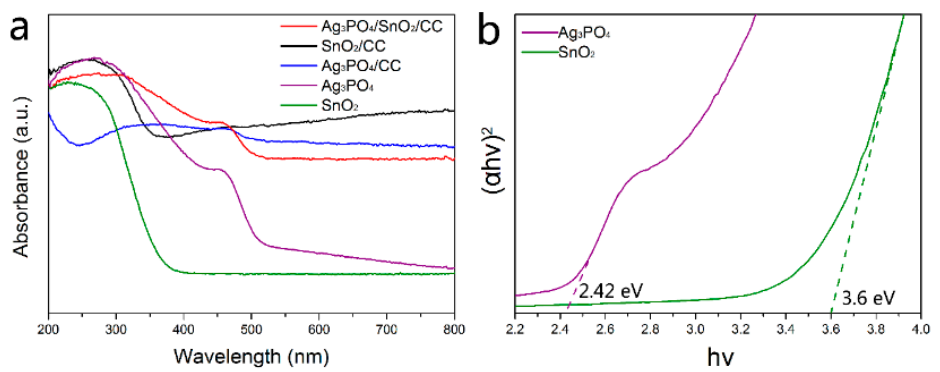

Figure 6. UV-vis diffuse reflectance spectra of the as-prepared samples (a). Plots of $(\alpha \mathrm{h} v)^{2}$ versus energy ( $\mathrm{h} v$ ) of the as-prepared $\mathrm{Ag}_{3} \mathrm{PO}_{4}$ and $\mathrm{SnO}_{2}(\mathbf{b})$. 


\subsection{Photocatalytic Performance}

The photocatalytic performances of the synthesized $\mathrm{SnO}_{2} / \mathrm{CC}, \mathrm{Ag}_{3} \mathrm{PO}_{4} / \mathrm{CC}$, and $\mathrm{Ag}_{3} \mathrm{PO}_{4} / \mathrm{SnO}_{2} / \mathrm{CC}$ samples were evaluated by photodegradation of the $\mathrm{RhB}$ and $\mathrm{MB}$ aqueous solution under visible light irradiation at room temperature. The $\mathrm{RhB}$ and $\mathrm{MB}$ are the popular probe molecule in heterogeneous catalytic reactions, showing the absorption peak at around $554 \mathrm{~nm}$ and $663 \mathrm{~nm}$ in the absorption spectra, respectively. The adsorption activities of the as-synthesized samples were evaluated prior to irradiation, and the results are shown in the Supplementary Materials Figure S1. After treatment for $60 \mathrm{~min}$, all the samples reached adsorption saturation. Figure 7 a shows the relationship between the concentration of $\mathrm{RhB}$ solution $\left(\mathrm{C} / \mathrm{C}_{0}\right)$ and visible light irradiation time for the synthesized samples, where $\mathrm{C}_{0}$ represents the initial concentration of $\mathrm{RhB}$ after adsorption equilibrium, and $\mathrm{C}$ represents the corresponding concentration at a certain time interval. It was clearly observed that the RhB solution, without the photocatalyst, shows only a little degradation under visible light irradiation. This reveals that the RhB solution, without the photocatalyst, is very stable under visible light irradiation. As can be seen in Figure $7 \mathrm{~b}$, the degradation rate of the synthesized $\mathrm{Ag}_{3} \mathrm{PO}_{4} / \mathrm{SnO}_{2} / \mathrm{CC}$ sample at $70 \mathrm{~min}$ is about $95.9 \%$, which is much higher than that of the synthesized $\mathrm{Ag}_{3} \mathrm{PO}_{4} / \mathrm{SnO}_{2}(79.2 \%), \mathrm{Ag}_{3} \mathrm{PO}_{4} / \mathrm{CC}(54.3 \%)$ and $\mathrm{SnO}_{2} / \mathrm{CC}(7.7 \%)$ samples. The results show that the RhB solution can be almost completely degraded by the $\mathrm{Ag}_{3} \mathrm{PO}_{4} / \mathrm{SnO}_{2} / \mathrm{CC}$ sample under visible light irradiation. However, only a certain percentage of the RhB solution can be degraded by the $\mathrm{Ag}_{3} \mathrm{PO}_{4} / \mathrm{CC}$ and $\mathrm{SnO}_{2} / \mathrm{CC}$ samples under the same conditions. Figure $7 \mathrm{c}$ shows the plot of the photodegradation rate constant of $\mathrm{RhB}$ versus degradation time. This reaction follows the pseudo-first-order reaction kinetic, which can be expressed as $\ln \left(C / C_{0}\right)=-k t$, where $\mathrm{k}$ and $\mathrm{t}$ represent the reaction rate constant and the reaction time, respectively. As illustrated in Figure $7 d$, the calculated $\mathrm{k}$ for the degradation of $\mathrm{RhB}$ over $\mathrm{Ag}_{3} \mathrm{PO}_{4} / \mathrm{SnO}_{2} / \mathrm{CC}$ is $0.04716 \mathrm{~min}^{-1}$, which is higher than those calculated for the reactions over $\mathrm{Ag}_{3} \mathrm{PO}_{4} / \mathrm{SnO}_{2}\left(0.02283 \mathrm{~min}^{-1}\right), \mathrm{Ag}_{3} \mathrm{PO}_{4} / \mathrm{CC}$ $\left(0.0113 \mathrm{~min}^{-1}\right)$ and $\mathrm{SnO}_{2} / \mathrm{CC}\left(0.00117 \mathrm{~min}^{-1}\right)$.

As shown in Figure $8 \mathrm{a}$, the $\mathrm{Ag}_{3} \mathrm{PO}_{4} / \mathrm{SnO}_{2} / \mathrm{CC}$ heterojunction exhibited the highest degradation rate of $\mathrm{MB}(96.6 \%)$ under visible light irradiation within $70 \mathrm{~min}$, which is far more than that of other catalysts. The reaction kinetics of MB photodegradation by various photocatalysts is also performed (Figure $8 \mathrm{~b}$ ). The value of $\mathrm{k}$ is determined to be $0.04916 \mathrm{~min}^{-1}, 0.0263 \mathrm{~min}^{-1}, 0.01347 \mathrm{~min}^{-1}$, $0.00401 \mathrm{~min}^{-1}$, and $0.00306 \mathrm{~min}^{-1}$ for the $\mathrm{Ag}_{3} \mathrm{PO}_{4} / \mathrm{SnO}_{2} / \mathrm{CC}, \mathrm{Ag}_{3} \mathrm{PO}_{4} / \mathrm{SnO}_{2}, \mathrm{Ag}_{3} \mathrm{PO}_{4} / \mathrm{CC}, \mathrm{SnO}_{2} / \mathrm{CC}$, and $\mathrm{MB}$ without a catalyst, respectively. The above results indicate that the photocatalytic efficiency of the sample significantly improved, when $\mathrm{Ag}_{3} \mathrm{PO}_{4}$ particles are deposited on the surface of $\mathrm{SnO}_{2} / \mathrm{CC}$.

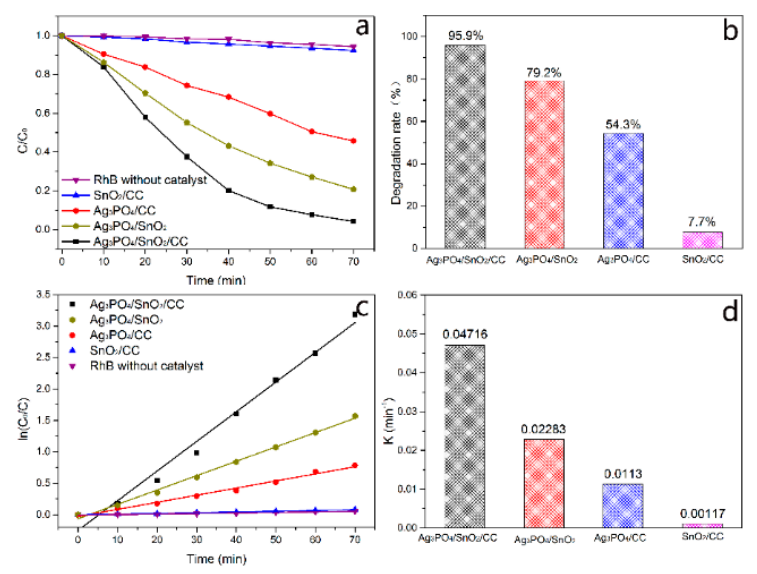

Figure 7. Time-course variation of $\mathrm{C} / \mathrm{C}_{0}$ of $\mathrm{RhB}$ over various catalysts (a). The degradation rate of various catalysts $(\mathbf{b})$. The plots of $\ln \left(\mathrm{C}_{0} / \mathrm{C}\right)$ versus time of various catalysts $(\mathbf{c})$. The calculated $k$ for the degradation of RhB over various catalysts (d). 

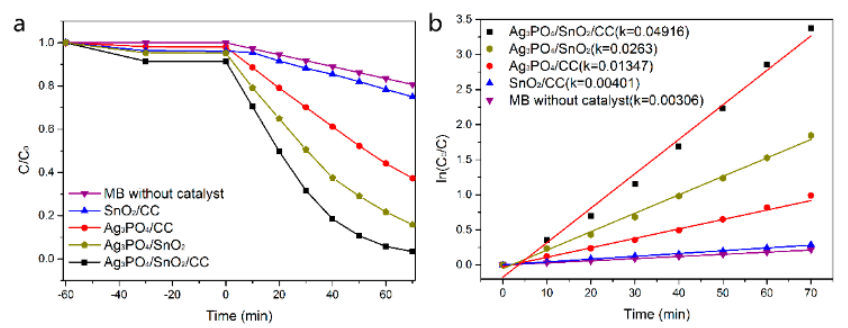

Figure 8. (a) Time-course variation of $C / C_{0}$ of $M B$ over various catalysts, (b) The plots of $\ln \left(C_{0} / C\right)$ versus time of various catalysts.

The stability and recycling of the $\mathrm{Ag}_{3} \mathrm{PO}_{4} / \mathrm{SnO}_{2} / \mathrm{CC}$ heterojunction were further analyzed and are shown in Figure 9a. After three cycling runs, the $\mathrm{Ag}_{3} \mathrm{PO}_{4} / \mathrm{SnO}_{2} / \mathrm{CC}$ photocatalysts still possess a high photocatalytic efficiency, up to $79.7 \%$. The SEM image of $\mathrm{Ag}_{3} \mathrm{PO}_{4} / \mathrm{SnO}_{2} / \mathrm{CC}$ after photocatalysis is shown in the Supplementary Materials Figure S2, and the structure and morphology of $\mathrm{Ag}_{3} \mathrm{PO}_{4} / \mathrm{SnO}_{2} / \mathrm{CC}$ is still well-preserved. To further study the dominant reactive species in photodegradation, radical trapping experiments of $\mathrm{Ag}_{3} \mathrm{PO}_{4} / \mathrm{SnO}_{2} / \mathrm{CC}$ were carried out. In this experiment, benzoquinone $(\mathrm{BQ}, 1.0 \mathrm{mmol} / \mathrm{L})$, ammonium oxalate $(\mathrm{AO}, 1.0 \mathrm{mmol} / \mathrm{L})$, and isopropyl alcohol (IPA, $0.5 \mathrm{~mL}$ ) were used as scavengers for $\cdot \mathrm{O}_{2}{ }^{-}, \mathrm{h}^{+}$and $\cdot \mathrm{OH}$, respectively [41]. The experimental results are displayed in Figure $9 \mathrm{~b}$, where $83.7 \%, 65.5 \%$ and $41.1 \%$ of $\mathrm{RhB}$ was degraded when the BQ, IPA and AO were added, respectively. This indicates that the photocatalytic reaction mainly depends on the $\mathrm{h}^{+}$, while $\cdot \mathrm{O}_{2}{ }^{-}$ and $\cdot \mathrm{OH}$ only have a slight effect. Therefore, the highly enhanced photodegradation achieved on $\mathrm{Ag}_{3} \mathrm{PO}_{4} / \mathrm{SnO}_{2} / \mathrm{CC}$ can be assigned to its heterostructure.
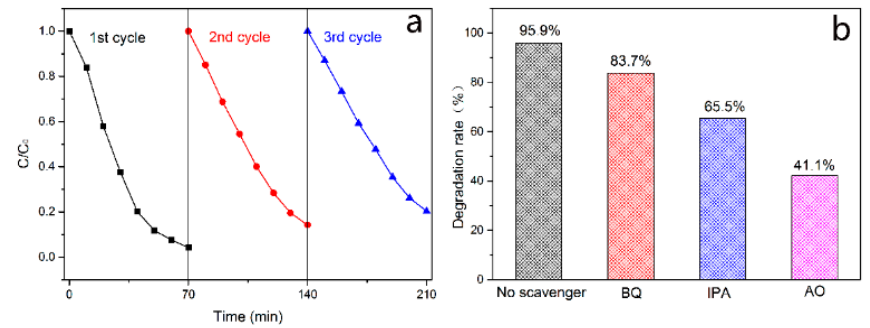

Figure 9. Stability study on the photocatalytic degradation of $\mathrm{RhB}$ over $\mathrm{Ag}_{3} \mathrm{PO}_{4} / \mathrm{SnO}_{2} / \mathrm{CC}$ heterojunction (a). Photocatalytic activities of the $\mathrm{Ag}_{3} \mathrm{PO}_{4} / \mathrm{SnO}_{2} / \mathrm{CC}$ heterojunction for the degradation of $\mathrm{RhB}$ in the presence of different scavengers (b).

Based on the experimental results above, a possible mechanism for highly efficient electron-hole separation is proposed, to explain the improved visible light photocatalytic properties of the $\mathrm{Ag}_{3} \mathrm{PO}_{4} / \mathrm{SnO}_{2} / \mathrm{CC}$ sample, as illustrated in Figure 10. The band structure of $\mathrm{Ag}_{3} \mathrm{PO}_{4}$ and $\mathrm{SnO}_{2}$ in the figure is drawn based on the data previously reported in other papers $[36,38,51,53,54]$. For the $\mathrm{Ag}_{3} \mathrm{PO}_{4} / \mathrm{SnO}_{2} / \mathrm{CC}$ heterojunction, the conduction band (CB) and valence band (VB) edge potentials of $\mathrm{Ag}_{3} \mathrm{PO}_{4}$ are more negative than that of $\mathrm{SnO}_{2}$ [36]. It is well-known that $\mathrm{SnO}_{2}$ has no absorption response to visible light [55]. However, $\mathrm{Ag}_{3} \mathrm{PO}_{4}$ can generate excited-state electrons and holes under visible light irradiation [56]. When the sample is under the visible light irradiation, the excited-state electrons in the $\mathrm{CB}$ of $\mathrm{Ag}_{3} \mathrm{PO}_{4}$ can easily be transferred to the surface of $\mathrm{SnO}_{2}$. Subsequently, electrons would migrate quickly to the surface of the carbon cloth, because of the one-dimensional structured $\mathrm{SnO}_{2}$ nanorods and excellent conductivity of the carbon cloth [42]. This further improves the separation efficiency of photogenerated electron-hole pairs. Eventually, the electrons in the carbon cloth reduce $\mathrm{O}_{2}$ to produce $\cdot \mathrm{O}_{2}{ }^{-}$for degrading $\mathrm{RhB}$ molecules, and the holes remaining at the $\mathrm{VB}$ of $\mathrm{Ag}_{3} \mathrm{PO}_{4}$ directly decompose the $\mathrm{RhB}$ into $\mathrm{CO}_{2}, \mathrm{H}_{2} \mathrm{O}$, and other inorganic molecules [47]. 


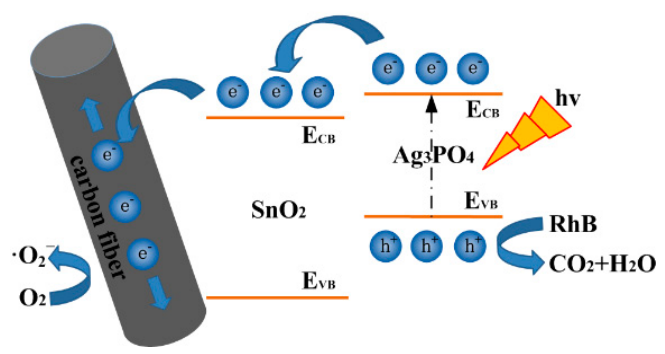

Figure 10. The schematic illustration of the photocatalytic mechanism of $\mathrm{Ag}_{3} \mathrm{PO}_{4} / \mathrm{SnO}_{2} / \mathrm{CC}$.

In order to reveal the separation and recombination of photogenerated electron-hole pairs of catalysts, Supplementary Materials Figure S3 shows the PL spectra of $\mathrm{Ag}_{3} \mathrm{PO}_{4} / \mathrm{CC}$ and $\mathrm{Ag}_{3} \mathrm{PO}_{4} / \mathrm{SnO}_{2} / \mathrm{CC}$ heterojunction. Generally, the lower PL intensity means that there is lower recombination of the photoinduced electron-hole pairs [57]. As shown in Supplementary Materials Figure S3, the PL intensity of $\mathrm{Ag}_{3} \mathrm{PO}_{4} / \mathrm{SnO}_{2} / \mathrm{CC}$ heterojunction is weaker, when compared with that of $\mathrm{Ag}_{3} \mathrm{PO}_{4} / \mathrm{CC}$, which can be attributed to the formation of the heterojunction between $\mathrm{Ag}_{3} \mathrm{PO}_{4}$ and $\mathrm{SnO}_{2}$ on carbon cloth.

Furthermore, it can be seen from Supplementary Materials Table S1 $[37,58,59]$ that the photocatalytic performance of the $\mathrm{Ag}_{3} \mathrm{PO}_{4} / \mathrm{SnO}_{2} / \mathrm{CC}$ heterojunction is much better than most of the results previously reported. This phenomenon is mainly caused by the following factors: Above all, the $\mathrm{Ag}_{3} \mathrm{PO}_{4} / \mathrm{SnO}_{2} / \mathrm{CC}$ heterojunction can effectively separate photogenerated electron-hole pairs, thereby improving the photocatalytic performance of the catalyst. Moreover, the carbon cloth with a large specific surface area serves as support for $\mathrm{Ag}_{3} \mathrm{PO}_{4} / \mathrm{SnO}_{2}$, which can help increase the specific surface area of the photocatalyst, thereby increasing the contact area of the catalyst with dye solution and visible light. As shown in Supplementary Materials Figure S4, the specific surface area of the photocatalyst has been significantly improved when introducing carbon cloth substrates.

\section{Conclusions}

In summary, the $\mathrm{Ag}_{3} \mathrm{PO}_{4} / \mathrm{SnO}_{2} / \mathrm{CC}$ heterojunction was successfully prepared via a facile two-step method. The structure and morphology characterization results of the as-prepared samples were described in detail. It can be clearly observed that many $\mathrm{Ag}_{3} \mathrm{PO}_{4}$ particles with irregular shapes are deposited on the surface of $\mathrm{SnO}_{2} / \mathrm{CC}$, forming the heterojunction. In the experiments using dye treatments, the $\mathrm{Ag}_{3} \mathrm{PO}_{4} / \mathrm{SnO}_{2} / \mathrm{CC}$ heterojunction reveals a higher photocatalytic performance for removing various contaminants $(\mathrm{RhB}, \mathrm{MB})$, than that of other as-prepared samples after 70 min under visible irradiation. This is mainly attributed to synergistic effects between the $\mathrm{Ag}_{3} \mathrm{PO}_{4}$ and $\mathrm{SnO}_{2}$ on carbon cloth, which can facilitate charge transfer and suppress the recombination of photogenerated electron-hole pairs, leading to the enhanced photocatalytic performance. Notably, the catalyst stability was maintained after three cycles. The structure and morphology of $\mathrm{Ag}_{3} \mathrm{PO}_{4} / \mathrm{SnO}_{2} / \mathrm{CC}$ after photocatalysis was still well-preserved. This indicates that the $\mathrm{Ag}_{3} \mathrm{PO}_{4} / \mathrm{SnO}_{2} / \mathrm{CC}$ heterojunction is a competitive candidate as an excellent photocatalyst, which has a high practical significance and application value for the future.

Supplementary Materials: The following are available online at http:/www.mdpi.com/2076-3417/10/9/3238/s1, Figure S1: The adsorption ability of the as-synthesized samples in the dark, Figure S2. The SEM image of $\mathrm{Ag}_{3} \mathrm{PO}_{4} / \mathrm{SnO}_{2} / \mathrm{CC}$ after photocatalysis. Figure S3. PL spectra of $\mathrm{Ag}_{3} \mathrm{PO}_{4} / C C$ and $\mathrm{Ag}_{3} \mathrm{PO}_{4} / \mathrm{SnO}_{2} / C C$, Figure S4. Nitrogen adsorption-desorption isotherms of $\mathrm{Ag}_{3} \mathrm{PO}_{4} / \mathrm{SnO}_{2}$ and $\mathrm{Ag}_{3} \mathrm{PO}_{4} / \mathrm{SnO}_{2} / \mathrm{CC}$, Table S1: Photocatalytic performance comparison of this work versus the previous published results.

Author Contributions: M.L. and G.W. conceived and designed the experiments; P.X. performed the experiments; Y.Z. and W.L. conducted sample characterizations. All authors participated in analysis of the experimental data and discussions of the results, as well as editing the manuscript. All authors have read and agreed to the published version of the manuscript.

Funding: The authors gratefully acknowledge financial support from the Foundation of Department of Science and Technology of He'nan Province (Grant No. 182102210295), the Foundation of He'nan Educational Committee 
(Grant No. 18B510007) and the Doctoral Scientific Research Foundation of Henan University of Science and Technology (Grant No. 400613480013).

Conflicts of Interest: The authors declare no conflict of interest.

\section{References}

1. Xue, H.; Chen, Q.; Jiang, F.; Yuan, D.; Lv, G.; Liang, L.; Liu, L.; Hong, M. A regenerative metal-organic framework for reversible uptake of Cd (II): From effective adsorption to in situ detection. Chem. Sci. 2016, 7, 5983-5988. [CrossRef] [PubMed]

2. Desai, A.V.; Manna, B.; Karmakar, A.; Sahu, A.; Ghosh, S.K. A water-stable cationic metal-organic framework as a dual adsorbent of oxoanion pollutants. Angew. Chem. Int. Ed. 2016, 55, 7811-7815. [CrossRef] [PubMed]

3. Duan, S.; Li, J.; Liu, X.; Wang, Y.; Zeng, S.; Shao, D.; Hayat, T. HF-free synthesis of nanoscale metal-organic framework NMIL-100(Fe) as an efficient dye adsorbent. ACS Sustain. Chem. Eng. 2016, 4, 3368-3378. [CrossRef]

4. Wang, B.; Lv, X.-L.; Feng, D.; Xie, L.-H.; Zhang, J.; Li, M.; Xie, Y.; Li, J.-R.; Zhou, H.-C. Highly stable $\mathrm{Zr}(\mathrm{IV})$-based metal-organic frameworks for the detection and removal of antibiotics and organic explosives in water. J. Am. Chem. Soc. 2016, 138, 6204-6216. [CrossRef]

5. Xu, P.; Shen, X.; Luo, L.; Shi, Z.; Liu, Z.; Chen, Z.; Zhu, M.; Zhang, L. Preparation of $\mathrm{TiO}_{2} / \mathrm{Bi}_{2} \mathrm{WO}_{6}$ nanostructured heterojunctions on carbon fibers as a weaveable visible-light photocatalyst/photoelectrode. Environ. Sci. Nano. 2018, 5, 327-337. [CrossRef]

6. Li, Y.-F.; Liu, Z.-P. Particle size, shape and activity for photocatalysis on titania anatase nanoparticles in aqueous surroundings. J. Am. Chem. Soc. 2011, 133, 15743-15752. [CrossRef]

7. Li, Z.; Luo, W.; Zhang, M.; Feng, J.; Zou, Z. Photoelectrochemical cells for solar hydrogen production: Current state of promising photoelectrodes, methods to improve their properties, and outlook. Energy Environ. Sci. 2013, 6, 347-370. [CrossRef]

8. Huang, Q.; Li, J. Enhanced photocatalytic and SERS properties of ZnO/Ag hierarchical multipods-shaped nanocomposites. Mater. Lett. 2017, 204, 85-88. [CrossRef]

9. Chen, X.; Liu, L.; Yu, P.Y.; Mao, S.S. Increasing solar absorption for photocatalysis with black hydrogenated titanium dioxide nanocrystals. Science 2011, 331, 746-750. [CrossRef]

10. Li, X.; Xia, T.; Xu, C.; Murowchick, J.; Chen, X. Synthesis and photoactivity of nanostructured CdS-TiO 2 composite catalysts. Catal. Today 2014, 225, 64-73. [CrossRef]

11. Liu, M.; Xu, P.; Zhang, J.; Liu, B. Preparation of MoS2@ZnO heterostructure with enhanced photocatalytic activity. Mater. Res. Express. 2019, 6, 045504. [CrossRef]

12. Du, Y.; Zhang, N.; Wang, C. Photo-catalytic degradation of trifluralin by $\mathrm{SnO}_{2}$-doped $\mathrm{Cu}_{2} \mathrm{O}$ crystals. Catal . Commun. 2010, 11, 670-674. [CrossRef]

13. Zhang, T.; Liu, Y.; Rao, Y.; Li, X.; Yuan, D.; Tang, S.; Zhao, Q. Enhanced photocatalytic activity of $\mathrm{TiO}_{2}$ with acetylene black and persulfate for degradation of tetracycline hydrochloride under visible light. Chem. Eng. J. 2020, 384, 123350. [CrossRef]

14. Wei, R.-B.; Huang, Z.-L.; Gu, G.-H.; Wang, Z.; Zeng, L.; Chen, Y.; Liu, Z.-Q. Dual-cocatalysts decorated rimous CdS spheres advancing highly-efficient visible-light photocatalytic hydrogen production. Appl. Catal. $B$ 2018, 231, 101-107. [CrossRef]

15. Xu, J.-W.; Gao, Z.-D.; Han, K.; Liu, Y.; Song, Y.-Y. Synthesis of magnetically separable $\mathrm{Ag}_{3} \mathrm{PO}_{4} / \mathrm{TiO}_{2} / \mathrm{Fe}_{3} \mathrm{O}_{4}$ heterostructure with enhanced photocatalytic performance under visible light for photoinactivation of bacteria. ACS Appl. Mater. Interfaces 2014, 6, 15122-15131. [CrossRef]

16. Liu, L.; Qi, Y.; Lu, J.; Lin, S.; An, W.; Liang, Y.; Cui, W. A stable $\mathrm{Ag}_{3} \mathrm{PO}_{4} @ g-\mathrm{C}_{3} \mathrm{~N}_{4}$ hybrid core@shell composite with enhanced visible light photocatalytic degradation. Appl. Catal. B 2016, 183, 133-141. [CrossRef]

17. Li, N.; Miao, S.; Zheng, X.; Lai, J.; Lv, S.; Gu, X.; Zhang, M.; Yang, J.; Cui, S. Construction of $\mathrm{Ag}_{3} \mathrm{PO}_{4} / \mathrm{BiNbO}_{4}$ heterojunction photocatalysts with high activity for rhodamine B removal under simulated sunlight irradiation. Ceram. Int. 2019, 45, 24260-24268. [CrossRef]

18. Shao, N.; Wang, J.; Wang, D.; Corvini, P. Preparation of three-dimensional $\mathrm{Ag}_{3} \mathrm{PO}_{4} / \mathrm{TiO}_{2} @ \mathrm{MoS}_{2}$ for enhanced visible-light photocatalytic activity and anti-photocorrosion. Appl. Catal. B 2017, 203, 964-978. [CrossRef] 
19. Chen, F.; Yang, Q.; Li, X.; Zeng, G.; Wang, D.; Niu, C.; Zhao, J.; An, H.; Xie, T.; Deng, Y. Hierarchical assembly of graphene-bridged $\mathrm{Ag}_{3} \mathrm{PO}_{4} / \mathrm{Ag} / \mathrm{BiVO}_{4}(040) \mathrm{Z}$-scheme photocatalyst: An efficient, sustainable and heterogeneous catalyst with enhanced visible-light photoactivity towards tetracycline degradation under visible light irradiation. Appl. Catal. B 2017, 200, 330-342. [CrossRef]

20. Liu, L.; Ding, L.; Liu, Y.; An, W.; Lin, S.; Liang, Y.; Cui, W. A stable $\mathrm{Ag}_{3} \mathrm{PO}_{4} @ P A N I$ core@shell hybrid: Enrichment photocatalytic degradation with $\pi-\pi$ conjugation. Appl. Catal. B 2017, 201, 92-104. [CrossRef]

21. Yu, H.; Cao, G.; Chen, F.; Wang, X.; Yu, J.; Lei, M. Enhanced photocatalytic performance of $\mathrm{Ag}_{3} \mathrm{PO}_{4}$ by simutaneous loading of Ag nanoparticles and Fe (III) cocatalyst. Appl. Catal. B 2014, 160, 658-665. [CrossRef]

22. Wang, W.; Sun, K.; Liu, H. Effects of different aluminum sources on morphologies and properties of ceramic floor tiles from red mud. Constr. Build. Mater. 2020, 241, 118119. [CrossRef]

23. Liu, X.; Xu, J.; Ni, Z.; Wang, R.; You, J.; Guo, R. Adsorption and visible-light-driven photocatalytic properties of $\mathrm{Ag}_{3} \mathrm{PO}_{4} / \mathrm{WO}_{3}$ composites: A discussion of the mechanism. Chem. Eng. J. 2019, 356, 22-33. [CrossRef]

24. Wang, Z.; Hu, T.; Dai, K.; Zhang, J.; Liang, C. Construction of Z-scheme $\mathrm{Ag}_{3} \mathrm{PO}_{4} / \mathrm{Bi}_{2} \mathrm{WO}_{6}$ composite with excellent visible-light photodegradation activity for removal of organic contaminants. Chinese J. Catal. 2017, 38, 2021-2029. [CrossRef]

25. Li, X.; Hu, H.; Xu, L.; Cui, C.; Qian, D.; Li, S.; Zhu, W.; Wang, P.; Lin, P.; Pan, J.; et al. Z-schematic water splitting by the synergistic effect of a type-II heterostructure and a highly efficient oxygen evolution catalyst. Appl. Surf. Sci. 2018, 441, 61-68. [CrossRef]

26. Cai, L.; Jiang, H.; Wang, L. Enhanced photo-stability and photocatalytic activity of $\mathrm{Ag}_{3} \mathrm{PO}_{4}$ via modification with $\mathrm{BiPO}_{4}$ and polypyrrole. Appl. Surf. Sci. 2017, 420, 43-52. [CrossRef]

27. An, Y.; Zheng, P.; Ma, X. Preparation and visible-light photocatalytic properties of the floating hollow glass microspheres- $\mathrm{TiO}_{2} / \mathrm{Ag}_{3} \mathrm{PO}_{4}$ composites. RSC Adv. 2019, 9, 721-729. [CrossRef]

28. Wan, Q.; Wang, T.H. Single-crystalline $\mathrm{Sb}$-doped $\mathrm{SnO}_{2}$ nanowires: Synthesis and gas sensor application. Chem. Commun. 2005, 30, 3841-3843. [CrossRef]

29. Liu, Z.; Sun, D.D.; Guo, P.; Leckie, J.O. An efficient bicomponent $\mathrm{TiO}_{2} / \mathrm{SnO}_{2}$ nanofiber photocatalyst fabricated by electrospinning with a side-by-side dual spinneret method. Nano Lett. 2007, 7, 1081-1085. [CrossRef]

30. Wang, C.; Zhou, Y.; Ge, M.; Xu, X.; Zhang, Z.; Jiang, J.Z. Large-scale synthesis of $\mathrm{SnO}_{2}$ nanosheets with high lithium storage capacity. J. Am. Chem. Soc. 2010, 132, 46-47. [CrossRef]

31. Wang, H.; Fu, F.; Zhang, F.; Wang, H.-E.; Kershaw, S.V.; Xu, J.; Sun, S.-G.; Rogach, A.L. Hydrothermal synthesis of hierarchical $\mathrm{SnO}_{2}$ microspheres for gas sensing and lithium-ion batteries applications: Fluoride-mediated formation of solid and hollow structures. J. Mater. Chem. 2012, 22, 2140-2148. [CrossRef]

32. Tian, W.; Zhang, C.; Zhai, T.; Li, S.-L.; Wang, X.; Liao, M.; Tsukagoshi, K.; Golberg, D.; Bando, Y. Flexible $\mathrm{SnO}_{2}$ hollow nanosphere film based high-performance ultraviolet photodetector. Chem. Commun. 2013, 49, 3739-3741. [CrossRef] [PubMed]

33. Zhang, H.; Feng, J.; Fei, T.; Liu, S.; Zhang, T. $\mathrm{SnO}_{2}$ nanoparticles-reduced graphene oxide nanocomposites for $\mathrm{NO}_{2}$ sensing at low operating temperature. Sens. Actuators B Chem. 2014, 190, 472-478. [CrossRef]

34. Reddy, C.V.; Babu, B.; Vattikuti, S.V.P.; Ravikumar, R.V.S.S.N.; Shim, J. Structural and optical properties of vanadium doped $\mathrm{SnO}_{2}$ nanoparticles with high photocatalytic activities. J. Lumin. 2016, 179, $26-34$. [CrossRef]

35. Lu, Z.; Luo, Y.; He, M.; Huo, P.; Chen, T.; Shi, W.; Yan, Y.; Pan, J.; Ma, Z.; Yang, S. Preparation and performance of a novel magnetic conductive imprinted photocatalyst for selective photodegradation of antibiotic solution. RSC Adv. 2013, 3, 18373-18382. [CrossRef]

36. Zhang, L.; Zhang, H.; Huang, H.; Liu, Y.; Kang, Z. $\mathrm{Ag}_{3} \mathrm{PO}_{4} / \mathrm{SnO}_{2}$ semiconductor nanocomposites with enhanced photocatalytic activity and stability. New J. Chem. 2012, 36, 1541-1544. [CrossRef]

37. Li, F.; Zhang, G.; Song, Y. Preparation and photocatalytic mechanism of $\mathrm{Ag}_{3} \mathrm{PO}_{4} / \mathrm{SnO}_{2}$ Composite Photocatalyst. Nano 2019, 14, 1950092. [CrossRef]

38. Chen, K.; Cao, M.; Ding, C.; Zheng, X. A green approach for the synthesis of novel $\mathrm{Ag}_{3} \mathrm{PO}_{4} / \mathrm{SnO}_{2} /$ porcine bone and its exploitation as a catalyst in the photodegradation of lignosulfonate into alkyl acids. RSC Adv. 2018, 8, 26782-26792. [CrossRef]

39. Amornpitoksuk, P.; Suwanboon, S.; Kaowphong, S. Photocatalytic activity of $\mathrm{AgCl} / \mathrm{SnO}_{2}$ prepared by one-pot green synthesis. Sustain. Chem. Pharm. 2019, 14, 100190. [CrossRef]

40. Huang, S.; Chen, J.; Zhong, J.; Li, J.; Hu, W.; Li, M.; Huang, K.; Duan, R. Enhanced photocatalytic performance of $\mathrm{Ag} / \mathrm{AgCl} / \mathrm{SnO}_{2}$ originating from efficient formation of $\mathrm{O}_{2}$. Mater. Chem. Phys. 2017, 201, 35-41. [CrossRef] 
41. Shen, X.; Zhang, T.; Xu, P.; Zhang, L.; Liu, J.; Chen, Z. Growth of $\mathrm{C}_{3} \mathrm{~N}_{4}$ nanosheets on carbon-fiber cloth as flexible and macroscale filter-membrane-shaped photocatalyst for degrading the flowing wastewater. Appl. Catal. B 2017, 219, 425-431. [CrossRef]

42. Zhang, W.; Sun, Y.; Xiao, Z.; Li, W.; Li, B.; Huang, X.; Liu, X.; Hu, J. Heterostructures of CuS nanoparticle/ZnO nanorod arrays on carbon fibers with improved visible and solar light photocatalytic properties. J. Mater. Chem. A 2015, 3, 7304-7313. [CrossRef]

43. Xu, P.; Wang, G.; Yan, J.; Zhang, Z.; Xu, M.; Cai, S.; Ruan, X.; Deng, Z. Reversible and high-capacity $\mathrm{SnO}_{2}$ /carbon cloth composite electrode materials prepared by magnetron sputtering for Li-ion batteries. Mater. Lett. 2017, 190, 56-59. [CrossRef]

44. Shen, Y.; Ren, X.; Qi, X.; Zhou, J.; Xu, G.; Huang, Z.; Zhong, J. Hydrothermal synthesis of NiSe 2 nanosheets on carbon cloths for photoelectrochemical hydrogen generation. J. Mater. Sci. Mater. Electron. 2017, 28, 768-772. [CrossRef]

45. Xu, M.; Jia, S.; Li, H.; Zhang, Z.; Guo, Y.; Chen, C.; Chen, S.; Yan, J.; Zhao, W.; Yun, J. In-situ growth of W18O49@carbon clothes for flexible-easy-recycled photocatalysts with high performance. Mater. Lett. 2018, 230, 224-227. [CrossRef]

46. Liu, M.; Xu, P.; Wang, G.; Yan, J. $\mathrm{SnO}_{2}$ Nanorod arrays grown on carbon cloth as a flexible binder-free electrode for high-performance lithium batteries. J. Electron. Mater. 2019, 48, 8206-8211. [CrossRef]

47. Liu, Y.; Wang, W.; Si, M.; Zhang, H. Carbon cloth-supported $\mathrm{MoS}_{2} / \mathrm{Ag}_{2} \mathrm{~S} / \mathrm{Ag}_{3} \mathrm{PO}_{4}$ composite with high photocatalytic activity and recyclability. ChemCatChem 2019, 11, 1017-1025.

48. Yan, J.; Xu, P.; Chen, S.; Wang, G.; Zhang, F.; Zhao, W.; Zhang, Z.; Deng, Z.; Xu, M.; Yun, J.; et al. Construction of highly ordered $\mathrm{ZnO}$ microrod@SnO $\mathrm{S}_{2}$ nanowire heterojunction hybrid with a test-tube brush-like structure for high performance lithium-ion batteries: Experimental and theoretical study. Electrochim. Acta 2020, 330, 135312. [CrossRef]

49. Yan, T.; Tian, J.; Guan, W.; Qiao, Z.; Li, W.; You, J.; Huang, B. Ultra-low loading of $\mathrm{Ag}_{3} \mathrm{PO}_{4}$ on hierarchical In2S3 microspheres to improve the photocatalytic performance: The cocatalytic effect of $\mathrm{Ag}$ and $\mathrm{Ag}_{3} \mathrm{PO}_{4}$. Appl. Catal. B 2017, 202, 84-94. [CrossRef]

50. Wang, L.; Gu, X.; Zhao, L.; Wang, B.; Jia, C.; Xu, J.; Zhao, Y.; Zhang, J. ZnO@TiO 2 heterostructure arrays/carbon cloth by charge redistribution enhances performance in flexible anode for $\mathrm{Li}$ ion batteries. Electrochim. Acta. 2019, 295, 107-112. [CrossRef]

51. Mei, J.; Zhang, D.; Li, N.; Zhang, M.; Gu, X.; Miao, S.; Cui, S.; Yang, J. The synthesis of $\mathrm{Ag}_{3} \mathrm{PO}_{4} / \mathrm{g}_{-} \mathrm{C}_{3} \mathrm{~N}_{4}$ nanocomposites and the application in the photocatalytic degradation of bisphenol A under visible light irradiation. J. Alloys Compd. 2018, 749, 715-723. [CrossRef]

52. Xu, M.; Yu, R.; Guo, Y.; Chen, C.; Han, Q.; Di, J.; Song, P.; Zheng, L.; Zhang, Z.; Yan, J.; et al. New strategy towards the assembly of hierarchical heterostructures of $\mathrm{SnO}_{2} / \mathrm{ZnO}$ for $\mathrm{NO}_{2}$ detection at a ppb level. Inorg. Chem. Front. 2019, 6, 2801-2809. [CrossRef]

53. Li, S.; Pan, J.; Li, H.; Liu, Y.; Ou, W.; Wang, J.; Song, C.; Zhao, W.; Zheng, Y.; Li, C. The transparent SnO/ZnO quantum dots $/ \mathrm{SnO}_{2}$ p-n junction towards the enhancement of photovoltaic conversion. Chem. Eng. J. 2019, 366, 305-312. [CrossRef]

54. Niu, M.; Huang, F.; Cui, L.; Huang, P.; Yu, Y.; Wang, Y. Hydrothermal synthesis, structural characteristics, and enhanced photocatalysis of $\mathrm{SnO} 2 / \alpha-\mathrm{Fe} 2 \mathrm{O} 3$ semiconductor nanoheterostructures. ACS Nano 2010, 4, 681-688. [CrossRef] [PubMed]

55. Xu, M.; Jia, S.; Chen, C.; Zhang, Z.; Yan, J.; Guo, Y.; Zhang, Y.; Zhao, W.; Yun, J.; Wang, Y. Microwave-assistant hydrothermal synthesis of $\mathrm{SnO}_{2} @ \mathrm{ZnO}$ hierarchical nanostructures enhanced photocatalytic performance under visible light irradiation. Mater. Res. Bull. 2018, 106, 74-80. [CrossRef]

56. Chen, S.; Huang, D.; Zeng, G.; Xue, W.; Lei, L.; Xu, P.; Deng, R.; Li, J.; Cheng, M. In-situ synthesis of facet-dependent $\mathrm{BiVO}_{4} / \mathrm{Ag}_{3} \mathrm{PO}_{4} / \mathrm{PANI}$ photocatalyst with enhanced visible-light-induced photocatalytic degradation performance: Synergism of interfacial coupling and hole-transfer. Chem. Eng. J. 2020, 382, 122840. [CrossRef]

57. He, Y.; Zhang, L.; Teng, B.; Fan, M. New application of Z-scheme $\mathrm{Ag}_{3} \mathrm{PO}_{4} / \mathrm{g}-\mathrm{C}_{3} \mathrm{~N}_{4}$ composite in converting $\mathrm{CO}_{2}$ to fuel. Environ. Sci. Technol. 2015, 49, 649-656. [CrossRef] 
58. Zhang, G.; Chen, D.; Li, N.; Xu, Q.; Li, H.; He, J.; Lu, J. SnS $2 / \mathrm{SnO}_{2}$ heterostructured nanosheet arrays grown on carbon cloth for efficient photocatalytic reduction of Cr (VI). J. Colloid Interface Sci. 2018, 514, 306-315. [CrossRef]

59. Cui, Z.; Sun, Y.; Zhang, Z.; Xu, M.; Xin, B. Facile synthesis and photocatalytic activity of $\mathrm{Ag}_{3} \mathrm{PO}_{4}$ decorated $\mathrm{MoS}_{2}$ nanoflakes on carbon fiber cloth. Mater. Res. Bull. 2018, 100, 345-352. [CrossRef]

(C) 2020 by the authors. Licensee MDPI, Basel, Switzerland. This article is an open access article distributed under the terms and conditions of the Creative Commons Attribution (CC BY) license (http://creativecommons.org/licenses/by/4.0/). 